\title{
Managing unused, damaged, and expired medications: Knowledge and attitudes among people of Malang, Indonesia
}

\author{
Hananditia Rachma Pramestutie*, Ayuk Lawuningtyas Hariadini, Tamara Gusti Ebtavanny, Ratna Kurnia Illahi, \\ Shafira Nur Ilmi \\ Department of Community Pharmacy, Faculty of Medicine, Brawijaya University, Malang, Indonesia.
}

\begin{tabular}{l}
\hline ARTICLE INFO \\
\hline Received on: 27/02/2021 \\
Accepted on: 13/06/2021 \\
Available online: 05/09/2021 \\
\hline Key words: \\
Knowledge, attitude, leftover \\
medicine, damage medicine, \\
expired medicine.
\end{tabular}

\section{INTRODUCTION}

Medicine is the most important part in the prevention of and recovery from diseases and may be utilized to improve the health of people, and therefore the intensity of people possessing medicines is relatively high. At present, the consumption of medications in the world has increased over the years. In Northern Uganda, $35.1 \%$ of households possess medications (Ocan et al., 2014). In Saudi Arabia, many people store insulin syringes, antibiotics, and cough syrup at home (Koshok et al., 2017). This is conducted because the medications could be utilized as selfmedication in the future, or even given to other family members if necessary (Angi'enda and Bukachi, 2016). However, storing medications at home may cause damage to medications when improperly stored, such as through being exposed to heat, direct

"Corresponding Author

Hananditia Rachma Pramestutie, Department of Community Pharmacy, Faculty of Medicine, Brawijaya University, Malang, Indonesia. E-mail: hananditia@ub.ac.id sunlight, and high moisture, causing the stability of medications to decrease and the dosage regiment to no longer be adequate. Additionally, storage of medications may increase the risk of medications exceeding their expiration dates (Kristina et al., 2018).

A study in Ethiopia revealed that $89.1 \%$ of medications that were purchased are not always perused by the people. Factors that contribute to medications no longer being utilized are changes in prescriptions, side effects of medications, unclear directions for taking medicines, improvement of conditions, and medications that have reached their expiration dates, which eventually leads to the disposal of the medications (Azad et al., 2012).One of the primary problems in the scope of healthcare and the environment in the world regards the improper disposal of leftover medications, damaged medications, and expired medications in households. This is because the basic knowledge regarding the proper disposal of medications is still low and thus may have effects on the surrounding environment (Dar et al., 2019). A study conducted by AlAzmi et al. (2017) showed that most medications are disposed of as household waste, such as through the trash, toilet, and sink (AlAzmi et al., 2017). Another research in Gujarat, India, showed 
that $30.5 \%$ of people disposed of medications in the household trash (Sonowal et al., 2017).

The knowledge of the people regarding the management of medications is also still low. A study conducted by Wasito et al. (2018) showed that the behaviors of people in Sidasari Wetan Hamlet, Cilacap, in storing medications are still very simple and conventional without paying attention to proper conditions, such as storing medications in combination with other objects, and they still store expired medications because their physical appearances still look good (Wasito et al., 2018). Effects that may arise from improper medication management are among others medication abuse, side effects ranging from light effects to death, and trade of counterfeit medications. Other effects also include reduction of therapy effectiveness, medication resistance, extension of recovery time, and increased healthcare costs (Koshok et al., 2017; Gul et al., 2016).

At present, in Indonesia, there exists a program to increase the knowledge of people on the management of medications from the time they are received to when they are disposed of in order to improve and correct the attitudes of people in managing medications. The educational program is called DAGUSIBU, encompassing four principles: obtain medications from proper places, peruse medications according to indications, store medications according to the instructions in their containers, and dispose of unused medications in the proper way (IAI, 2014). In obtaining medications, it is important to consider proper places such as pharmacies, licensed drugstores, clinics, and hospitals to ensure their benefits, safety, and quality. In addition, obtaining and usage of medications also require paying attention to their expiration dates. Medication storage also needs to be considered because improper medication storage can cause the substance contained in the medications to be damaged and the medications to be unusable (Pankajkumar, 2016).

The background above indicates that the knowledge and attitudes of the people on the management of leftover medications, damaged medications, and expired medications are still low. The low level of knowledge of the people on the management of leftover medications, damaged medications, and expired medications, specifically their storage and disposal, is accompanied by the uncaring attitudes of the people in managing those medications. The proper management of medications should follow DAGUSIBU, in which medications are to be stored in special containers and before disposing of medications, they must be crushed or dissolved first.Previous studies in Uganda, Saudi Arabia, and Ethiopia have only described descriptively that most people have stored medicines at home; however, the majority of household members lack knowledge on proper disposal of drugs that remain from previous treatment. They suggest that there is an urgent need to develop public awareness and education on medical waste (Azad et al., 2012; Koshok et al., 2017; Ocan et al., 2014). Therefore, the focus of this research was to find out more about the influence of knowledge and attitudes of the community in the management of leftover, damaged, and expired medication in the Greater Malang area. Besides, this problem has not been studied in Greater Malang Raya. It is considered necessary in order to determine the relationship between knowledge and attitudes of the community in the management of leftover, damaged, and expired medication, and it is hoped that the results of this research can be used as evaluation materials for pharmacies, pharmacy installations, and other health services to provide more information related to drug management to increase knowledge and change the attitude of the Greater Malang area community about the management of leftover, damaged, and expired medication.

\section{MATERIALS AND METHODS}

\section{Research design}

This research is an analytic observational research with a cross-sectional design. Sample collection was performed with the convenience sampling technique on people who reside in the Greater Malang region, covering the City of Malang, Malang Regency, and the City of Batu, in the period from May to June 2020.

\section{Research population and sample}

The population in this research is the people residing in the City of Malang, Malang Regency, and the City of Batu. The sample in this research is people older than 18 years, residing in the Greater Malang (City of Malang, Malang Regency, and City of Batu), and storing at least one kind of unused medication at home. The exclusion criteria are people who have difficulty in communicating through digital media and people who do not wish to become respondents. The sample size for this research was determined with the Slovin sample size formula:

$$
n=\frac{N}{1+N \cdot e^{2}}
$$

where $N$ is the number of populations present in the City of Malang $(N=874,890)$, Malang Regency $(N=2,619,975)$, and the City of Batu $(N=218,458)$, while the $e$ value (error tolerance limit or critical value) is the value of $10 \%$. From the results of sample calculations, the obtained minimum sample amount is 300 respondents (100 samples from the City of Malang, 100 samples from Malang Regency, and 100 samples from the City of Batu).

\section{Research instrument}

This research was conducted with questionnaires on the knowledge and attitudes of people regarding the management of leftover, damaged, and expired medications that had been composed and developed by the researcher. Validity and reliability testing had been conducted on the questionnaires as distributed to respondents online through Google Forms. Validity and reliability testing were conducted on 30 nonsample respondents. The validity of the research instrument was measured by the Pearson productmoment correlation, while the reliability of the instrument was measured by the Cronbach alpha reliability coefficient.

The utilized questionnaire on the knowledge of people regarding the management of leftover, damaged, and expired medications is composed of 15 close-ended questions that ask about medication constraints (definition, characteristics, and causative factors), method of storage, and method of disposal of leftover medications, damaged medications, and expired medications. The questionnaire is evaluated with a score of 1 for correct answers and a score of 0 for incorrect answers. The questionnaire on the attitudes of people regarding the management of leftover medications, damaged medications, and expired medications is composed of 10 questions that ask about the attitudes of the people 
in accepting, responding, evaluating, organizing, and understanding the management of leftover medications, damaged medications, and expired medications. The questions are measured with a Likert scale, which for favorable questions is strongly agree $=5$, agree $=$ 4 , uncertain $=3$, disagree $=2$, and strongly disagree $=1$ and for unfavorable questions is strongly agree $=1$, agree $=2$, uncertain $=$ 3 , disagree $=4$, and strongly disagree $=5$. The favorable questions on the questionnaire are numbers $4,6,7,8$, and 10 , while the unfavorable questions are numbers $1,2,3,5$, and 9 .

The questionnaires were distributed online with Google Forms. Posters were created containing a QR code for the research questionnaires that respondents could then scan. The posters were distributed in pharmacies in the Greater Malang. The posters also included in detail the inclusion and exclusion criteria for this research.

\section{Data analysis}

The level of knowledge of people regarding the management of leftover medications, damaged medications, and expired medications was found through the total score of the questionnaire. The total score was converted into percentage (\%) form with the following formula:

$$
P=\frac{F}{N} \times 100 \%
$$

where $P$ denotes the percentage score, $F$ denotes the number of correct answers, and $N$ denotes the number of questions.

The obtained results were categorized as shown in Table 1.

The attitudes of people regarding the management of leftover medications, damaged medications, and expired medications were categorized with the $T$ score. The $T$ score is utilized to categorize attitudes through the Likert scale. Categorization of attitudes was based on the mean $T$. The formula for calculating the $T$ score is as follows:

$$
T=50+10\left[\frac{x-\bar{x}}{s}\right]
$$

where $x$ denotes the respondent score; $\bar{x}$ denotes the average group score; $s$ denotes the standard deviation. The obtained results were categorized as shown in Table 2.

The utilized test to find the relationship between the knowledge and attitudes of people of Greater Malang on medication management was the Spearman test.

Table 1. Categories of knowledge levels.

\begin{tabular}{lc}
\hline \multicolumn{1}{c}{ Score } & Category \\
\hline $76 \%-100 \%$ & Good \\
$56 \%-75 \%$ & Fair \\
$<56 \%$ & Poor \\
\hline
\end{tabular}

Table 2. Attitude categories.

\begin{tabular}{lc}
\hline \multicolumn{1}{c}{ Category } & T score \\
\hline Positive & $>50$ \\
Negative & $\leq 50$ \\
\hline
\end{tabular}

\section{RESULTS AND DISCUSSION}

The obtained samples for the research are 322 respondents from the areas of the City of Malang (114 respondents), Malang Regency (106 respondents), and the City of Batu (102 respondents). For this research, the sociodemographic characteristics of the respondents are shown in Table 3.

Most of the respondents were adults (26-65 years of age), $69.57 \%$ (224 respondents). Age can affect the response and thought patterns of people toward certain objects. As people grow older, their response, thought patterns, motor skills, intellectual skills, verbal skills, and problem-solving skills also develop further (Kusturica et al., 2012). A study conducted by Dawood et al. (2017) indicated that knowledge about medicine decreases as people grow older and become elderly, which may be because an advanced age and a decrease in cognitive knowledge occur (Dawood et al., 2017). Most of the respondents were of the female gender, $80.43 \%$ (259 respondents). Women possess more free time to participate in the research compared to men, and they have greater knowledge of medicine than men (Akici et al., 2018).

Most of the respondents had college-level education, $64.91 \%$ (209 respondents). A high level of education will allow a person to think logically and rationally and thus be able to solve problems with analyses, as in the field of health or medicine (Pradono and Sulistyowati, 2014). Most of the respondents work as private employees, $29.19 \%$ (94 respondents). Most respondents had monthly incomes of less than Rp. 1,500,000, 33.85\% (109 respondents), and the fewest had monthly incomes of Rp. 1,500,000-Rp. 2,500,000, 18.01\% (58 respondents). People with higher economic statuses and better working environments are able to obtain better experience and knowledge in rational usage of medicine (Fidora, 2018).

Other characteristics of respondents in relation to storage and disposal of medications cover sources of information, reasons for storing medications at home, and methods of medication disposal (Table 4).

The source of information for most respondents on medication management was from electronic media, 31.37\% (101 respondents), and from an apothecary or other health officials, $30.12 \%$ (97 respondents). Electronic media is a facility for communication. All forms of mass media such as electronic media possess a major influence in forming the opinions and beliefs of individuals. The presence of new information will provide new cognitive foundations and therefore affects the knowledge and attitudes of people (Zhao and Zhang, 2017).

All of the respondents in this research possess medicine at home, with the most frequent reason being supply, 89.44\% (288 respondents). People may possess and store medication at home for self-medication to relieve complaints or symptoms of illnesses before deciding to seek assistance from health officials or other health service facilities. Yet, it needs to be known that not all medications can be possessed for self-medication (Bennadi, 2014; Kahnamouei-aghdam et al., 2017). For the method of disposing of medications at home, most respondents $(49.38 \%$ or 159 respondents) throw them away into the trash. The results showed that the way respondents dispose of medications in the household is still not appropriate to proper medication disposal methods. Before they are disposed of, medications should be processed 
Table 3. Demographic data of respondents.

\begin{tabular}{|c|c|c|}
\hline Demography & $\begin{array}{l}\text { Frequency } \\
\quad(n)\end{array}$ & $\begin{array}{l}\text { Percentage } \\
(\%)\end{array}$ \\
\hline \multicolumn{3}{|l|}{ Age } \\
\hline Young adult (18-25 years) & 94 & 29.19 \\
\hline Adult (26-65 years) & 224 & 69.57 \\
\hline Elderly ( $>65$ years) & 4 & 1.24 \\
\hline \multicolumn{3}{|l|}{ Gender } \\
\hline Male & 63 & 19.57 \\
\hline Female & 259 & 80.43 \\
\hline \multicolumn{3}{|l|}{ Education } \\
\hline Elementary school (SD/MI/equivalent) & 3 & 0.93 \\
\hline Middle school (SMP/MTs/equivalent) & 4 & 1.24 \\
\hline $\begin{array}{l}\text { High/vocational school (SMA/MA/SMK/ } \\
\text { equivalent) }\end{array}$ & 106 & 32.92 \\
\hline College (Diploma/Sarjana S1/S2/S3) & 209 & 64.91 \\
\hline \multicolumn{3}{|l|}{ Occupation } \\
\hline Student & 57 & 17.70 \\
\hline Civil servants & 70 & 21.74 \\
\hline Private employee & 94 & 29.19 \\
\hline Entrepreneur & 41 & 12.73 \\
\hline Household wives & 54 & 16.77 \\
\hline Unemployed & 6 & 1.86 \\
\hline \multicolumn{3}{|c|}{ Monthly income } \\
\hline$<$ Rp. $1,500,000$ & 109 & 33.85 \\
\hline Rp. $1,500,000-2,500,000$ & 58 & 18.01 \\
\hline Rp. $2,500,000-3,500,000$ & 66 & 20.50 \\
\hline$>$ Rp. $3,500,000$ & 89 & 29.67 \\
\hline
\end{tabular}

first; tablets are to be crushed before being buried in soil, while liquids are to be dissolved in water and then disposed of in the sewer (Khan et al., 2019). The research results showed similar behaviors of people in Yogyakarta and Malang for the disposal of medications, in that people still throw away leftover medications, damaged medications, and expired medications into the trash. This is because of a lack of knowledge by people regarding medication disposal. Continuous improper disposal of medications may cause environmental damage and other health problems (Kristina et al., 2018).

The role of pharmacists in Indonesia in providing drugrelated information is regulated in a Regulation of the Minister of Health concerning Standards for Pharmaceutical Services in Pharmacies. The pharmacy higher education curriculum is also structured to achieve these competencies. In addition, the Indonesian Pharmacist Association (IAI) and Badan Pengawas Obat dan Makanan (The Indonesian Food and Drug Authority) also work together with the Ministry of Health $(\mathrm{MoH})$ in educating the public through campaigns in the mass media regarding drug storage and disposal (Table 5).

Table 6 shows the results of the questionnaire of respondent knowledge in managing leftover medications, damaged medications, and expired medications.
Table 4. Characteristics of respondents in relation to medication management.

\begin{tabular}{lcc}
\hline \multicolumn{1}{c}{ Source of information } & $\begin{array}{c}\text { Frequency } \\
(\boldsymbol{n})\end{array}$ & $\begin{array}{c}\text { Percentage } \\
\mathbf{( \% )}\end{array}$ \\
\hline Apothecary/pharmacist/other health & 97 & 30.12 \\
officials & 101 & 31.37 \\
Electronic media & 90 & 27.95 \\
Medication packaging/label & 22 & 6.83 \\
Magazines/books/leaflets/posters & 4 & 1.24 \\
Friend/relative & 8 & 0.25 \\
Never obtained information & & \\
Reasons for storing medications at home & 26 & 8.07 \\
Medication is still good & 1 & 0.31 \\
Expense & 288 & 89.44 \\
Supply & 2 & 0.62 \\
Not known & 5 & 15.63 \\
Others (leftover from doctor/ & & \\
treatment) & & \\
Method of medication disposal & 159 & 49.38 \\
Directly into the trash & 81 & 25.16 \\
Prior processing (crushed/dissolved) & 2 & 0.62 \\
Mixed with coffee or other liquids & 20 & 6.21 \\
Separation of packaging and contents & 12 & 3.73 \\
Burning & 7 & 2.17 \\
Burial & 4 & 1.24 \\
Cutting up & 12 & 3.73 \\
Into the toilet/sewer & & 0.31 \\
Into the river & & 7.45 \\
Never disposed & & \\
\hline & & \\
\hline
\end{tabular}

Based on the data for the results of the questionnaire on the level of respondent knowledge on the management of leftover medications, damaged medications, and expired medications, the categories of respondent levels of knowledge were found, as indicated in Table 6.

For the level of respondent knowledge on the management of leftover medications, damaged medications, and expired medications, most have fair knowledge with a percentage of $58 \%$ (186 respondents), while $21 \%$ (67 respondents) have good knowledge and 21\% (69 respondents) have poor knowledge. There is a lack of understanding by the people of medication management at home, such as proper ways to store medications and disposing of medications that are damaged or expired (Bashaar et al., 2017). The research conducted by Wasito et al. (2018) in Sidasari Wetan Hamlet, Cilacap, also showed that most people have poor knowledge. People still store medications in very simple and conventional ways without paying attention to proper conditions, such as storing medications together with other objects because of not having special containers such as a medicine box (Wasito et al., 2018). A lack of knowledge in the storage and disposal of medications may cause mistakes or inappropriate behaviors, which in turn will result in various health and environmental problems. If medications are stored and 
Table 5. Role of pharmacist in Indonesia.

\begin{tabular}{|c|c|c|}
\hline $\begin{array}{c}\text { Pharmaceutical service standard (Indonesian } \\
\text { Ministry of Health, 2019) }\end{array}$ & $\begin{array}{l}\text { Learning outcomes of undergraduate pharmacy and } \\
\text { pharmacist profession (APTFI, 2021) }\end{array}$ & $\begin{array}{l}\text { Campaign by the Indonesian } \\
\text { Pharmacist Association (IAI, } \\
\text { 2014) }\end{array}$ \\
\hline $\begin{array}{l}\text { Provide information and drug education to patients } \\
\text { or their families, especially for drugs to be used } \\
\text { independently by the patient regarding } \\
\text { 1. Indications } \\
\text { 2. Dosage } \\
\text { 3. Time and how to take or use the drug } \\
\text { 4. Expected therapeutic results } \\
\text { 5. How to store the drug } \\
\text { 6. Side effects if needed, and other things that must } \\
\text { be considered during drug use. }\end{array}$ & $\begin{array}{l}\text { The formulation of learning outcomes is divided into three domains: } \\
\text { 1. Knowledge } \\
\text { 2. Work ability } \\
\text { 3. Authority and responsibility } \\
\text { Domains related to managing unused, damaged, and expired } \\
\text { medications are work ability: } \\
\text { a. Able to evaluate and develop strategies with an evidence-based } \\
\text { approach in pharmaceutical preparation services to optimize the } \\
\text { therapy } \\
\text { b. Actively involved in monitoring drug use, collaborative work } \\
\text { between professions, public health services maintaining a } \\
\text { patient-centered perspective. }\end{array}$ & $\begin{array}{l}\text { The Drug Awareness Family } \\
\text { Movement (GKSO) is a program } \\
\text { launched by the IAI, which is a joint } \\
\text { effort with the MoH and the Food } \\
\text { and Drug Administration (BPOM) } \\
\text { to increase public understanding } \\
\text { of drugs through the socialization } \\
\text { of DAGUSIBU (Get, Use, Store, } \\
\text { and Dispose) drugs properly. This } \\
\text { campaign is carried out through } \\
\text { the mass media, both print and } \\
\text { electronic. }\end{array}$ \\
\hline
\end{tabular}

Table 6. Results of the questionnaire on the level of knowledge of respondents.

\begin{tabular}{|c|c|c|c|c|c|}
\hline \multirow[t]{2}{*}{ No } & \multirow[t]{2}{*}{ Statement } & \multicolumn{2}{|c|}{ True } & \multicolumn{2}{|c|}{ False } \\
\hline & & $n$ & $\%$ & $n$ & $\%$ \\
\hline 1. & $\begin{array}{l}\text { The date at which point medication can no longer be utilized after the first time the medication is opened is } \\
\text { called the expiration date of the medication. }\end{array}$ & 115 & 37.71 & 207 & 64.29 \\
\hline 2. & Medications exposed to direct sunlight will not experience damage. & 285 & 88.51 & 37 & 11.49 \\
\hline 3. & Hard-shell capsules that become soft in storage can still be consumed. & 301 & 93.48 & 21 & 6.52 \\
\hline 4. & One of the characteristics of expired tablet medications is swollen packages. & 246 & 76.40 & 76 & 23.60 \\
\hline 5 & $\begin{array}{l}\text { Liquid medications that contain oil and still separate into two parts even after being shaken are still safe to be } \\
\text { consumed. }\end{array}$ & 249 & 77.33 & 73 & 22.67 \\
\hline 6. & Sediment in syrup medications is a normal occurrence and the medicine can be consumed/utilized again. & 167 & 51.86 & 155 & 48.14 \\
\hline 7. & Leftover medicines in liquid form can be stored in the freezer to preserve them. & 215 & 66.77 & 107 & 33.23 \\
\hline 8. & Syrup medications that have been opened can still be consumed after 3 months. & 262 & 81.37 & 60 & 18.63 \\
\hline 9. & $\begin{array}{l}\text { Compound ointment medications that have been opened may be utilized and stored up to the indicated } \\
\text { expiration date. }\end{array}$ & 94 & 29.19 & 228 & 70.81 \\
\hline 10. & Powdered medications that are stored in plastic for more than 30 days can still be utilized. & 267 & 83 & 55 & 17 \\
\hline 11. & Medications will be quickly damaged if they are stored with other objects in a single container. & 258 & 80.12 & 64 & 19.88 \\
\hline 12. & Syrup medications that are no longer utilized/damaged/expired may be disposed directly into the sink. & 125 & 38.82 & 197 & 61.18 \\
\hline 13. & Apothecaries cannot help to process medications that are no longer utilized/damaged/expired. & 110 & 34.16 & 212 & 65.84 \\
\hline 14. & Tablet medications are disposed of by crushing them and mixing them with water, salt, or coffee grounds. & 219 & 68.01 & 103 & 31.99 \\
\hline 15. & This medication is disposed of by first separating the packaging and its contents. & 257 & 79.81 & 65 & 20.19 \\
\hline
\end{tabular}

disposed of arbitrarily, there is a possibility that other people may end up with them and consume them, which may then threaten their health (Viswasanthi et al., 2018). The behavior of disposing medications directly to sewage without proper destruction will also cause environmental damage; not only are people affected, but also plants and animals will also be affected. Medication residue is a pure source of wastewater contamination. In a research conducted in Europe, many pharmaceutical substances were found in groundwater, wastewater, and drinking water. If the wastewater leaks to the groundwater, which is usually utilized for everyday needs such as agriculture and irrigation as well as for consumption or drinking water, this may cause serious threats to health in the long term or even death (AlAzmi et al., 2017; Heba Shaaban et al., 2018).

Table 7 presents the data for the questionnaire of attitudes of people in managing leftover medications, damaged medications, and expired medications.

Based on the data for the results of the questionnaire on respondent attitudes on the management of leftover medications, damaged medications, and expired medications, the categories of respondent attitudes were found, as indicated in Table 8.

The categories of respondent attitudes as shown in Table 9 show that $52 \%$ (168 respondents) had a negative attitude 
Table 7. Category of levels of knowledge of respondents.

\begin{tabular}{lcc}
\hline \multicolumn{1}{c}{ Level of knowledge } & Frequency $(\boldsymbol{n})$ & Percentage \\
\hline Good & 67 & 21 \\
Fair & 186 & 58 \\
Poor & 69 & 21 \\
\hline
\end{tabular}

toward the management of leftover medications, damaged medications, and expired medications. Meanwhile, 48\% (154 respondents) had a positive attitude. The results imply that the attitudes of people in managing leftover medications, damaged medications, and expired medications are still not appropriate to methods or ways of management that are proper and safe. In line with a study in Jeddah, respondent attitudes in managing medications are still uncaring. This is indicated by respondent attitudes in considering that throwing away medications in the trash is more environmentally friendly than other disposal methods (AlAzmi et al., 2017). Another research in Yogyakarta also indicated that a majority of respondents have uncaring attitudes, as they dispose of medications into household trash and still store leftover medications at home past their expiration dates (Kristina et al., 2018). Attitudes of managing medications in a proper and safe manner become a primary concern. The presence of medication accumulations in the soil, water, and drinking water becomes one of the proofs of improper attitudes in managing medications (Tong et al., 2011). Although in Indonesia there are not yet any studies regarding this matter, it is likely that compounds of medicines have accumulated in the environment. Considering the studies conducted in Malang and Yogyakarta, most respondents have not conducted proper and safe processing of medications. Attitudes of people may be affected by personal experience and cultural influence, and this occurs among the people. Even if the people possess knowledge in proper management of medications, because the experience seen in the environments of the family and local people culture is not in line, the possessed knowledge tends to be ignored. Furthermore, the local culture is one that tends to seek the easy way out, and thus people do not attempt to do things as they should be done-in this case storing and disposing of leftover, damaged, or expired medications-and thus they are more comfortable in disposing medications directly into the trash (Chacko et al., 2020; Viswasanthi et al, 2018).

Correlation testing (Spearman's test) (Table 10) was performed to find out the relationship between the two variables, such as the level of knowledge of and attitudes in managing leftover, damaged, and expired medications. In Table 10, the obtained significance value $(p)$ was 0.173 , and this indicates that there is no relationship between the level of knowledge and attitude of the people in managing leftover, damaged, and expired medications, as the value of $p>0.05$. The value of the correlation coefficient was 0.076 , which indicates a very weak correlation between the two positive variables. These results showed that no relationship exists between the level of knowledge and attitude. Good knowledge is not necessarily realized in good behaviors as well. The level of knowledge possessed by respondents in

Table 8. Results of the questionnaire on the attitudes of respondents.

\begin{tabular}{|c|c|c|c|c|c|c|}
\hline No & Statement & SA & $\mathbf{A}$ & $\mathbf{U}$ & D & SD \\
\hline \multirow[t]{2}{*}{1} & \multirow{2}{*}{$\begin{array}{l}\text { I am accustomed to storing medications at home until they have gone } \\
\text { past their expiration dates }\end{array}$} & 16 & 88 & 32 & 113 & 73 \\
\hline & & $4.97 \%$ & $27.33 \%$ & $9.94 \%$ & $35.09 \%$ & $22.67 \%$ \\
\hline \multirow[t]{2}{*}{2} & \multirow{2}{*}{$\begin{array}{l}\text { I throw away leftover/damaged/expired medications directly into the } \\
\text { trash }\end{array}$} & 18 & 76 & 84 & 87 & 57 \\
\hline & & $5.59 \%$ & $23.6 \%$ & $26.09 \%$ & $27.02 \%$ & $17.7 \%$ \\
\hline \multirow[t]{2}{*}{3} & \multirow{2}{*}{$\begin{array}{l}\text { I still utilize medications that look good without looking at their } \\
\text { expiration dates }\end{array}$} & 4 & 13 & 14 & 134 & 157 \\
\hline & & $1.24 \%$ & $4.04 \%$ & $4.35 \%$ & $41.61 \%$ & $48.76 \%$ \\
\hline \multirow[t]{2}{*}{4} & \multirow{2}{*}{$\begin{array}{l}\text { I seek information regarding proper ways to dispose of leftover/ } \\
\text { damaged/expired medications }\end{array}$} & 78 & 146 & 68 & 26 & 4 \\
\hline & & $24.22 \%$ & $45.34 \%$ & $21.12 \%$ & $8.07 \%$ & $1.24 \%$ \\
\hline \multirow[t]{2}{*}{5} & \multirow{2}{*}{$\begin{array}{l}\text { I think that storing liquid medications in the freezer will preserve the } \\
\text { medications }\end{array}$} & 10 & 72 & 94 & 104 & 42 \\
\hline & & $3.11 \%$ & $22.36 \%$ & $29.19 \%$ & $32.3 \%$ & $13.04 \%$ \\
\hline \multirow[t]{2}{*}{6} & \multirow{2}{*}{$\begin{array}{l}\text { I think that throwing away leftover/damaged/expired medications by } \\
\text { disposing them into the sink will cause environmental pollution }\end{array}$} & 52 & 141 & 88 & 37 & 4 \\
\hline & & $16.15 \%$ & $43.79 \%$ & $27.33 \%$ & $11.49 \%$ & $1.24 \%$ \\
\hline \multirow[t]{2}{*}{7} & \multirow{2}{*}{$\begin{array}{l}\text { I store medications in a special container for medications and not } \\
\text { together with other objects }\end{array}$} & 159 & 140 & 13 & 9 & 1 \\
\hline & & $49.38 \%$ & $43.48 \%$ & $4.04 \%$ & $2.80 \%$ & $0.31 \%$ \\
\hline \multirow[t]{2}{*}{8} & \multirow{2}{*}{$\begin{array}{l}\text { I am responsible for finding appropriate ways to dispose of leftover/ } \\
\text { damaged/expired medications that I have }\end{array}$} & 80 & 166 & 61 & 14 & 1 \\
\hline & & $24.84 \%$ & $51.55 \%$ & $18.94 \%$ & $4.35 \%$ & $0.31 \%$ \\
\hline \multirow[t]{2}{*}{9} & \multirow{2}{*}{$\begin{array}{l}\text { When I obtain medications in powdered form, I can store them for } \\
\text { more than } 30 \text { days }\end{array}$} & 5 & 30 & 69 & 173 & 45 \\
\hline & & $1.55 \%$ & $9.32 \%$ & $21.43 \%$ & $53.73 \%$ & $13.98 \%$ \\
\hline \multirow[t]{2}{*}{10} & \multirow{2}{*}{$\begin{array}{l}\text { If there are facilities to dispose of leftover/damaged/expired } \\
\text { medications, I am willing to utilize those facilities }\end{array}$} & 165 & 141 & 14 & 2 & 0 \\
\hline & & $51.24 \%$ & $43.79 \%$ & $4.35 \%$ & $0.62 \%$ & $0 \%$ \\
\hline
\end{tabular}

$\mathrm{SA}=$ strongly agree; $\mathrm{A}=$ agree $\mathrm{U}=$ uncertain $\mathrm{D}=$ disagree $; \mathrm{SD}=$ strongly disagree. 
Table 9. Category of respondent attitudes.

\begin{tabular}{lcc}
\hline \multicolumn{1}{c}{ Attitude } & Frequency (n) & Percentage \\
\hline Positive & 154 & 48 \\
Negative & 168 & 52 \\
\hline
\end{tabular}

Table 10. Correlation testing of level of knowledge and attitude.

\begin{tabular}{ccc}
\hline \multicolumn{1}{c}{ Variable } & Significance value & $\begin{array}{c}\text { Correlation } \\
\text { coefficient }\end{array}$ \\
\hline $\begin{array}{l}\text { Level of knowledge } \\
\text { and attitude }\end{array}$ & 0.173 & 0.076 \\
\hline
\end{tabular}

managing medications is in the "fair" category, but the attitudes of the people are still negative in that they still do not conduct proper management of medications. The results are in line with the research conducted by Sonowal et al. (2017) in that respondents possess the knowledge about methods of and places for disposal of medications, but in their execution, respondent attitudes are not in line with the possessed knowledge, which is indicated by the fact that respondents still dispose medications into the sewer (Sonowal et al., 2017). The formation of new attitudes begins in the cognitive domain as a representation of what is believed by individuals possessing the attitude. However, a person may act without having to know the meaning or stimulus being received. In other words, attitude does not have to be based on knowledge. The formation of attitudes may also be affected by several factors, such as personal experience, culture, influence of others, mass media, educational institutions or religious institutions, and emotions within an individual. Fundamentally, the attitude of a person in theory may be affected or formed by possessed knowledge, experience, and information from mass media; yet the attitudes of people sometimes undergo a process wherein the cognitive component related to the possessed knowledge does not correlate with the conative component, and thus what is known is not executed in the form of actions. This is commonly recognized as "cognitive dissonance." Therefore, based on the explanation above, it can be understood that the cognitive component of attitude, as appropriate knowledge in the management of medicine, is not in line with the conative component of attitude, as everyday attitudes in good and proper management of medicine (Ali et al., 2018; Williams et al., 2009). Considering the explanation above, pharmacist is the profession that plays a role in medicine. One of the roles of pharmacists in relation to the storage and disposal of medicines is to provide counseling, information, and education. In this way, pharmacists are expected to provide education on the proper ways of managing medications and the importance of doing so (Alfadl et al., 2018; Layqah, 2018). There should also be innovations from pharmacies, for example, by handing out leaflets containing management methods for leftover, damaged, and expired medications to the people, while medicines are being provided at the pharmacy or when conducting communication, information, and education service activities. With the development of technology, another method that could be implemented by pharmacists to improve knowledge and attitudes in the management of medications is to initiate a national collaborative campaign and a campaign of consciousness with the usage of social media (Albaroodi, 2019; Al-Shareef et al., 2016). A review done by Rahmadani and Kristina (2021) showed that some countries including United States, Australia, Egypt, Mexico, and Malaysia also had programs that assisted in returning unused medicines. Most of the programs were held in pharmacies, as they were considered reliable to manage the disposal of unused drugs and easy to access by community. The numbers of drugs collected were varied from hundreds of dose units up to more than 69 million dose units and from different classes of therapy including analgesics and antimicrobial therapy. This return of medicine program could pose as a solution for the increasing problems due to incorrect disposal of medicines, including sewage management and economic burden caused by the high cost of medicine removal (Rahmadani and Kristina, 2021).

\section{CONCLUSION}

Most of the people of the Greater Malang area possess knowledge regarding the management of leftover, damaged, and expired medications, which is within the "fair" category. For attitudes, most of the people of the Greater Malang area possess negative attitudes for the management of leftover, damaged, and expired medications. Results of correlation testing of knowledge and attitudes of the people of the Greater Malang area on the management of leftover, damaged, and expired medications show that there is no significant relationship. Pharmacists need to take up the role to educate the people of the Greater Malang area on the management of leftover, damaged, and expired medications in order to be able to store and manage medicines at home properly. This is because increasing knowledge is the first step to changing behavior.

\section{ACKNOWLEDGMENTS}

Gratitude is due to the Faculty of Medicine of Brawijaya University for funding this research through tuition grants from the faculty in 2020 .

\section{AUTHOR CONTRIBUTIONS}

All authors made substantial contributions to conception and design, acquisition of data, or analysis and interpretation of data; took part in drafting the article or revising it critically for important intellectual content; agreed to submit to the current journal; gave final approval of the version to be published; and agreed to be accountable for all aspects of the work.

\section{ETHICAL APPROVAL}

This research has been declared ethical by the Ethics Commission of the Faculty of Medicine, Brawijaya University, with notice number 114/EC/KEPK/06/2020.

\section{CONFLICT OF INTEREST}

The author declared no potential conflicts of interest with respect to the research, authorship, and/or publication of this article.

\section{REFERENCES}

Akici A, Aydin V, Kiroglu A. Assessment of the association between drug disposal practices and drug use and storage behaviors. Saudi Pharm J, 2018; 26(1):7-13. 
AlAzmi A, AlHamdan H, Abualezz R, Bahadig F, Abonofal N, Osman M. Patients' knowledge and attitude toward the disposal of medications. J Pharm, 2017; 28(2):1-9.

Albaroodi KAI. Pharmacists' knowledge regarding drug disposal in Karbala. Pharmacy, 2019; 7(2):57.

Alfadl A.A., Alrasheedy AA, Alhassun MS. Evaluation of medication counseling practice at community pharmacies in Qassim Region, Saudi Arabia. Saudi Pharm J, 2018; 26(2):258-62.

Ali SA, Suhail N, Ali S. Community pharmacies in rural. I-Manager's J Nurs, 2018; 6(1):17-27.

Al-Shareef F, El-Asrar SA, Al-Bakr L, Al-Amro M, Alqahtani F, Aleanizy F, Al-Rashood S. Investigating the disposal of expired and unused medication in Riyadh, Saudi Arabia: a cross-sectional study. Int J Clin Pharm, 2016; 38(4):822-28.

Angi'enda SA, Bukachi SA. Household knowledge and perceptions on disposal practices of unused medicines in Kenya. J Anthropol Archaeology, 2016; 4(2):1-20.

Azad AK, Ansary RH, Akhter A, Al-Mamun SMM, Uddin M, Rahman MM. Disposal practice for unused medications among the students of the international Islamic University Malaysia. J Appl Pharm Sci, 2012; 2(7):101-6.

Bashaar M., Thawani V, Hassali MA, Saleem F. Disposal practices of unused and expired pharmaceuticals among general public in Kabul. BMC Public Health, 2017; 17(1):1-8.

Bennadi D. Self-medication: a current challenge. J Basic Clin Pharm, 2014; 5(1):19.

Chacko CT, Prakash D, Hafsa P, Joseph L, Shabaraya AR. A review on the attitude and practice on self medication, storage and disposal of drugs in a community. Int J Res Rev, 2020; 7(8):122-29.

Dar MA, Maqbool M, Rasool S. Pharmaceutical wastes and their disposal practice in routine. Int J Inf Comput Sci, 2019; 6:76-92.

Dawood OT, Hassali MA, Saleem F. Factors affecting knowledge and practice of medicine use among the general public in the State of Penang, Malaysia. J Pharm Health Serv Res, 2017; 8(1):51-7.

Fidora AF. Knowledge and barriers to safe disposal of pharmaceutical products entering the environment. Dissertation Abstr Int B Sci Eng, 2018; 79(4-B(E)).

Gul A, Nazish S, Sabir S, Nazish H, Masood T. Expired drugsawareness and practices of outdoor patients. J Rawalpindi Med Coll Student Suppl, 2016; 20(1):45-8.

Heba Shaaban H, Alghamdi AM, Alhamed N, Alziadi A. Environmental contamination by pharmaceutical waste : assessing patterns of disposing unwanted medications and investigating the factors influencing personal disposal choices. J Pharmacol Pharm Res, 2018; 1(1):003.

IAI. 2014. Pedoman Pelaksanaan Gerakan Keluarga Sadar Obat. Pengurus Pusat Ikatan Apoteker Indonesia. Jakarta.

Kahnamouei-aghdam F, Zakeri A, Amani F, Sajjadifar M, Mohammadi P, Ojaghi H. Self-medication prevalence and related factors among medical university students. Int J Basic Clin Pharmacol, 2017; 6(2):373.

Khan BA, Cheng L, Khan AA, Ahmed H. Healthcare waste management in Asian developing countries: a mini review. Waste Manage Res, 2019; 37(9):863-75.

Koshok M, Jan T, Altawil S, Alghamdi E, Ali A, Sobh A, Gamal M. Awareness of home drug storage and utilization habits: Saudi study. Med Sci | Int Med J, 2017; 6(4):1.
Kristina SA, Wiedyaningsih C, Cahyadi A, Ridwan BA. A survey on medicine disposal practice among households in Yogyakarta. Asian J Pharm, 2018; 12(3):S955-58.

Kusturica MP, Sabo A, Tomic Z, Horvat O, Šolak Z. Storage and disposal of unused medications: knowledge, behavior, and attitudes among Serbian people. Int J Clin Pharm, 2012; 34(4):604-10.

Layqah L. The practice of counseling in pharmacy: patients' perspectives. J Anal Pharm Res, 2018; 7(4):472-76.

Ocan M, Bbosa GS, Waako P, Ogwal-Okeng J, Obua C. Factors predicting home storage of medicines in Northern Uganda. BMC Public Health, 2014; 14(1):1-7.

Pankajkumar PD. Storage and disposal of medicines in home among students. J Pharm Res, 2016; 10(5):290-95.

Pradono J, Sulistyowati N. Hubungan Antara Tingkat Pendidikan, Pengetahuan Tentang Kesehatan Lingkungan, Perilaku Hidup Sehat Dengan Status Kesehatan (Studi Korelasi Pada Penduduk Umur 1024 Tahun Di Jakarta Pusat). Buletin Penelitian Sistem Kesehatan, 2014; 17(1):89-95.

Rahmadani, Mufti Alifia, and Susi Ari Kristina. 2021. "A Scoping Review of Disposal of Unused Medicines in Take-Back Programs" 11 (1): 73-90.

Sonowal S, Desai C, Kapadia JD, Desai MK. A survey of knowledge, attitude, and practice of consumers at a tertiary care hospital regarding the disposal of unused medicines. J Basic Clin Pharm, 2017; 8(1):4

Tong AYC, Peake BM, Braund R. Disposal practices for unused medications in New Zealand community pharmacies. J Prim Health Care, 2011; 3(3):197-203.

Viswasanthi A, Bhasha G, Rajitha M. A qualitative study of the knowledge, attitude and practice of patients regarding the use of expired and disposal of unused medicine at Nimra Institute of Medical Sciences, Vijayawada. Perspect Clin Res, 2018; 6(1):1-4.

Wasito H, Pratiwi H, Wibowo A, Solihat NK. Edukasi Dan Peningkatan Kualitas Pengelolaan Obat Di Rumah Tangga: Studi Kasus Di Dusun Sidasari Wetan Desa Kubangkangkung Kawunganten Cilacap (Education and quality improvement of drug management in family: a case study at Dusun Sidasari Wetan, Kubang. J Aplikasi Teknik Dan Pengabdian Masyarakat, 2018; 2(2):93.

Williams N, Robertson J, McGorm K, Roberts K, Elton R. What factors affect medication-storage practice among patients on methadone maintenance treatment? Int J Pharm Pract, 2009; 17(4):231-35.

Zhao Y, Zhang J. Consumer health information seeking in social media: a literature review. Health Info Libr J, 2017; 34(4):268-83.

\section{How to cite this article:}

Pramestutie HR, Hariadini AL, Ebtavanny TG, Illahi RK, Ilmi SN. Managing unused, damaged, and expired medications: Knowledge and attitudes among people of Malang, Indonesia. J Appl Pharm Sci, 2021; 11(09):102-109. 